\title{
PENGARUH PENGGUNAAN ABU SABUT KELAPA SAWIT SEBAGAI BAHAN PENAMBAH SEMEN TERHADAP KUAT TEKAN PAVING BLOCK
}

\author{
Agustin Gunawan $^{1)}$,Febriyan Abimanyu ${ }^{1)}$, Yuzuar Afrizal ${ }^{1)}$, \\ ${ }^{1)}$ Program Studi Teknik Sipil, Fakultas Teknik UNIB \\ Jl. W.R. Supratman Kandang Limun, Kota Bengkulu 38371 \\ Corresponding author : febriyanabimanyu@gmail.com
}

\begin{abstract}
Abstrak
Penelitian ini dilatarbelakangi dengan banyaknya jumlah limbah industri pengolahan kelapa sawit yang tak terolah dan kandungan silika yang dimiliki Abu Sabut kelapa Sawit (ASKS). Tujuan penelitian ini adalah untuk mengetahui kuat tekan paving block yang menggunakan abu sabut kelapa sawit sebagai bahan penambah semen. Metode yang digunakan dalam penelitian ini adalah metode eksperimen. Proses pembuatan paving block dilakukan dengan cara yang dibuat di pabrik. Paving block memiliki ukuran $20 \mathrm{~cm}$ x $10 \mathrm{~cm}$ x $6 \mathrm{~cm}$ dengan perbandingan semen dan pasir adalah 1pc : 3ps. Variasi penambahan ASKS sebesar 0\%, 2,5\%, 5\%, 7,5\%, $10 \%, 12,5 \%$ dan $15 \%$ terhadap volume semen. Jumlah total benda uji sebanyak 35, dengan 5 benda uji untuk masing-masing variasinya. Kebutuhan air pada setiap campuran mengacu pada SNI 03-6882-2002. Paving block dicetak secara manual dan direndam selama 12 hari, kemudian umur 13 hari dipotong berbentuk kubus dengan sisi $5 \mathrm{~cm}$ dan diuji pada umur 14 hari. Hasil kuat tekan rata-rata paving block pada variasi 0\%, 2,5\%, 5\%, 7,5\%, 10\%, 12,5\% dan 15\% berturut-turut adalah 15,13 $\mathrm{MPa}, 15,22 \mathrm{MPa}, 15,78 \mathrm{MPa}, 16,44 \mathrm{MPa}, 16,53 \mathrm{MPa}, 13,77 \mathrm{MPa}$ dan $10,37 \mathrm{MPa}$. Nilai kuat tekan paving block terbesar terjadi pada variasi penambahan $10 \%$ (meningkat 9,25\% dari paving block normal (variasi 0\%)) dan mengalami penurunan terbesar pada variasi $15 \%$ yaitu sebesar $-31,51 \%$ dari paving block normal.
\end{abstract}

Kata kunci : paving block, kuat tekan, abu sabut kelapa sawit

\begin{abstract}
The research is motivated by the large amount of untreated oil palm industrial waste, with a silica contet. This research was aimed to find the compressive strengh of paving block that use oil palm fiber ash as the added material to cement. This research method was experimental. The paving block making prosess was done in the way which the factory did. The specimens made had a size of $20 \mathrm{~cm} \times 10 \mathrm{~cm} \times 6 \mathrm{~cm}$ with a ratio of 1 cement $: 3$ sand. The variations of the ash addition were consecutively $0 \%, 2,5 \%, 5 \%, 7,5 \%, 10 \%, 12,5 \%$ and $15 \%$ to the volume of cement. The total number of specimens was 35, with 5 pieces for each variation. Water requirement in each mixture referred to SNI 03-6882-2002. Paving block was formed manually, soaked for 12 days, then at the age of 13 days paving block was cut into cubes with $5 \mathrm{~cm}$ on each side and tested for compressive strength at the age of 14 days. The results of the average compressive strength of paving block in each variation were consecutively 15,13 MPa, 15,22 MPa, 15,78 MPa, 16,44 Mpa, 16,53 MPa, 13,77 MPa and 10,37 MPa. The highest value of compressive strength occurred on the addition of $10 \%$ which was equal to 16,53 $\mathrm{MPa}$ (increased by 9,25\% from the normal paving block (variation of 0\%) and the largest decrease occurred on the variation of 15\% (-31,51\% from the normal paving block).
\end{abstract}

Keywords : paving block, compressive strength, oil palm fiber ash 


\section{PENDAHULUAN}

Paving block dibuat dengan cara mencampurkan pada komposisi tertentu semen, pasir, dan air, kemudian dilakukan pressing dengan intensitas tertentu dan perawatannya dilakukan dengan membasahi permukaan paving block dan dibiarkan sampai mengeras. Kekuatan untuk menahan gaya tekan merupakan salah satu karakteristik kualitas yang harus dimiliki paving block. Semakin tinggi kuat tekan, maka akan semakin baik pula kualitas paving block (Muliyasih, 2011 dalam Hambali dkk., 2013).

Paving block pada umumnya dibuat dengan panjang antara 200-250 mm dan lebar antara 100-112 mm. Ketebalan paving block yang sering digunakan berkisar antara 60-100 mm (Andre, 2012 dalam Hambali dkk., 2013).

Indonesia merupakan negara dengan jumlah produksi kelapa sawit terbesar di dunia. Jumlah produksi yang besar tersebut berbanding lurus dengan jumlah limbah padat yang dihasilkan dan belum termanfaatkan (Tegar dkk., 2016). Sabut kelapa sawit adalah hasil samping yang berasal dari ampas perasan buah kelapa sawit yang diambil minyaknya. Kandungan silika yang berasal dari abu sabut kelapa sawit mencapai 59,1\% (Graille dkk., 1985 dalam Jalali, 2017). Silika merupakan salah satu unsur utama yang terkandung dalam semen portland sehingga memungkinkan abu sabut kelapa sawit dapat digunakan sebagai bahan penambah pada campuran paving block yang dapat melebihi mutu dari paving block normal tanpa harus menambahnya lagi dengan semen.

Penelitian ini membahas mengenai bagaimana pengaruh abu sabut kelapa sawit sebagai bahan penambah semen terhadap kuat tekan paving block berumur 14 hari. Penelitian ini diharapkan dapat mengurangi

J.Inersia.12(1)12-17 limbah sabut kelapa sawit yang ada di pabrik-pabrik pengolahan kelapa sawit.

Permasalahan yang dibahas dalam penelitian ini yaitu bagaimana pengaruh penggunaan abu sabut kelapa sawit sebesar 0\%, 2,5\%, $5 \%, 7,5 \%, 10 \%, 12,5 \%$, dan $15 \%$ sebagai bahan penambah semen dalam pembuatan paving block dengan menggunakan metode konvensional terhadap kuat tekan paving block 1pc : $3 \mathrm{ps}$.

Tujuan penelitian ini adalah untuk mengetahui kuat tekan paving block $1 \mathrm{pc}: 3 \mathrm{ps}$ yang menggunakan abu sabut kelapa sawit sebesar $0 \%, 2,5 \%, 5 \%, 7,5 \%$, $10 \%, 12,5 \%$, dan $15 \%$ sebagai bahan penambah semen pada paving block berumur 14 hari.

\section{METODE PENELITIAN}

Penelitian menggunakan metode eksperimen dengan menggunakan abu sabut kelapa sawit sebagai bahan penambah semen dalam pembuatan paving block. Variasi persentase abu sabut kelapa sawit yang digunakan adalah $0 \%, 2,5 \%, 5 \%, 7,5 \%, 10 \%, 12,5 \%$ dan $15 \%$ terhadap volume semen. Masingmasing variasi dibuat 5 sampel dengan menggunakan agregat halus atau pasir yang digunakan berasal dari daerah Selolong, Kecamatan Lais, Kabupaten Bengkulu Utara, Provinsi Bengkulu. Pengaruh variasi persentase penggunaan abu sabut kelapa sawit sebagai bahan penambah semen ini diketahui berdasarkan uji kuat tekan paving block pada umur 14 hari. Paving block dibuat berbentuk balok dengan ukuran $20 \mathrm{~cm} \times 10 \mathrm{~cm} \times 6 \mathrm{~cm}$. Pada saat akan dilakukan uji kuat tekan, paving block dipotong sehingga berbentuk kubus sesuai dengan SNI 03-0691-1996, dengan ukuran sisi sebesar $5 \mathrm{~cm}$.

\section{Tahapan persiapan penelitian}

Tahapan persiapan penelitian yang dilakukan meliputi tahapan persiapan bahan, 
pengujian sifat fisis material dan persiapan alat. Persiapan bahan meliputi persiapan abu sabut kelapa sawit, agregat halus, semen dan air. Pengujian sifat fisis meliputi pengujian kadar air, kadar lumpur, berat isi, berat jenis, analisa saringan, kadar organik, dan uji visual. Persiapan alat meliputi semua alat yang digunakan pada penelitian ini.

\section{Alat}

Peralatan yang digunakan dalam penelitian ini tersedia di Laboratorium Konstruksi dan Teknologi Beton Program Studi Teknik Sipil Fakultas Teknik Universitas Bengkulu, sedangkan alat yang digunakan untuk pembuatan paving block sudah tersedia di pabrik pembuatan paving block. Alat-alat yang digunakan dalam penelitian ini adalah :

1. Alat dari pabrik pembuatan paving block:

a. Cetakan paving block berbentuk balok dengan dimensi panjang $20 \mathrm{~cm}$, lebar $10 \mathrm{~cm}$ dan tebal $6 \mathrm{~cm}$

b. Gablokan atau pemukul

c. Sekop

2. Alat dari Laboratorium Konstruksi dan Teknologi Beton Program Studi Teknik Sipil Fakultas Teknik Universitas Bengkulu :
a. Alat uji kuat tekan (Cement Compression Machine).
b. Alat uji sebar pasta yang terdiri dari meja dan cincin leleh

c. Mesin gerinda

d. Ayakan/saringan

e. Sendok semen

f. Alat penumbuk dan perata

g. Mold

h. Kerucut terpancung dan penumbuk

i. Gelas ukur

j. Timbangan

k. Ember

1. Nampan

m. Alat tulis dan penggaris

n. Kain lap

o. Piknometer

p. Talam, mold dan tongkat pemadat q. Warna standar organik plate

r. Cawan dan ember

s. Jangka sorong

\section{Bahan}

1. Abu sabut kelapa sawit

Sabut kelapa sawit yang digunakan berasal dari pabrik pengolahan minyak kelapa sawit yang berada di Desa Pulau Panggung, Kecamatan Talang Empat, Kabupaten Bengkulu Tengah, Provinsi Bengkulu. Sabut kelapa sawit dibersihkan dari kotoran yang menempel kemudian dijemur hingga kering lalu dibakar di atas loyang hingga menjadi abu. Abu sabut kelapa sawit yang sudah dibakar didiamkan selama 24 jam dan kemudian diayak menggunakan ayakan no. 100 dan selanjutnya dilakukan pengujian berat isi dan didapatkan berat isi abu sabut kelapa sawit rata-rata adalah $0,47 \mathrm{gr} / \mathrm{cm}^{3}$. Abu sabut kelapa sawit dapat dilihat pada Gambar 1.

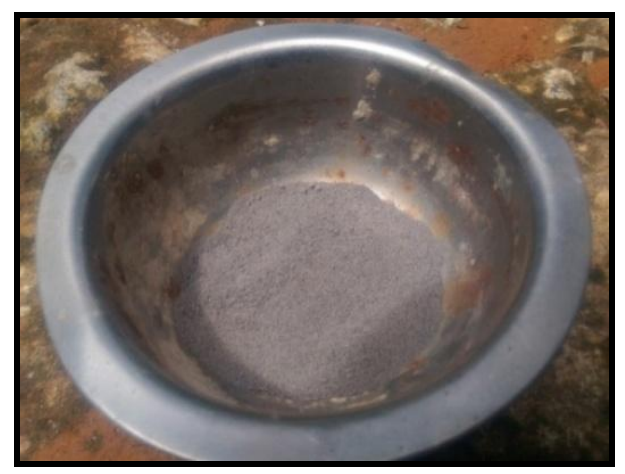

Gambar 1. Abu Sabut Kelapa Sawit

2. Agregat halus

Pasir yang digunakan diambil langsung dari pabrik pembuatan paving block yaitu pasir yang berasal dari daerah Selolong, Kecamatan Lais, Kabupaten Bengkulu Utara, Provinsi Bengkulu. Pasir yang digunakan dapat dilihat pada Gambar 2. Pasir selanjutnya dihamparkan di atas terpal hingga mengalami kering permukaan atau SSD (Saturated Surface Dry). 


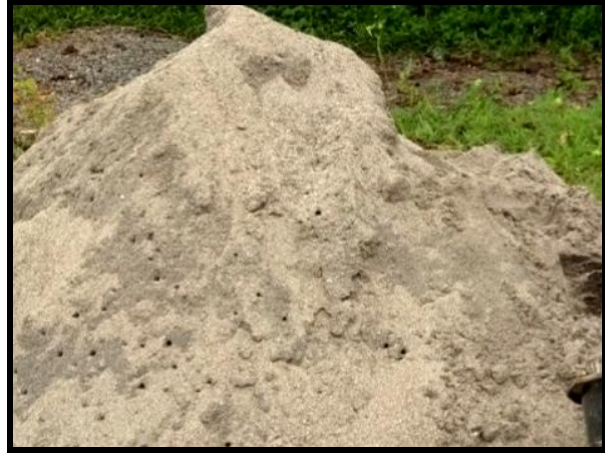

Gambar 2. Agregat Halus

Pemeriksaan uji fisis dilakukan pada agregat halus. Pemeriksaan ini dilakukan menurut standar yang berlaku. Hasil pemeriksaan agregat halus dapat dilihat pada Tabel 1

Tabel 1. Pemeriksaan Agregat Halus

\begin{tabular}{|c|l|c|c|}
\hline No. & $\begin{array}{c}\text { Nama } \\
\text { Pemeriksaan }\end{array}$ & Hasil & $\begin{array}{c}\text { Syarat } \\
\text { (SNI) }\end{array}$ \\
\hline 1 & $\begin{array}{l}\text { Analisa } \\
\text { Saringan (\%) }\end{array}$ & 1,54 & $1,5-3,8$ \\
\hline 2 & Kadar Air (\%) & 4,09 & - \\
\hline 3 & $\begin{array}{l}\text { Kadar } \\
\text { Lumpur (\%) }\end{array}$ & 2,33 & Maks. 5\% \\
\hline 4 & Berat Jenis & 2,58 & $2,5-2,7$ \\
\hline 5 & $\begin{array}{l}\text { Berat Isi } \\
\text { (gr/cm }{ }^{3}\end{array}$ & 1,62 & $>1,2$ \\
\hline 6 & $\begin{array}{l}\text { Kadar } \\
\text { Organik }\end{array}$ & No. 5 & $\begin{array}{c}\text { Maks. no. } \\
11\end{array}$ \\
\hline
\end{tabular}

3. Semen

Semen yang digunakan adalah semen PCC sesuai SNI 15-7064-2004. Semen diuji secara visual dan dilakukan pemeriksaan berat isi dan Hasil pemeriksaan berat isi semen rata-rata adalah $1,38 \mathrm{gr} / \mathrm{cm}^{3}$. Pengujian secara visual dilakukan dengan melakukan pengamatan pada kemasan semen. Kemasan semen harus dalam keadaan baik, tertutup, dan segel kemasan tidak mengalami kerusakan. Semen dapat dilihat pada Gambar 3 .

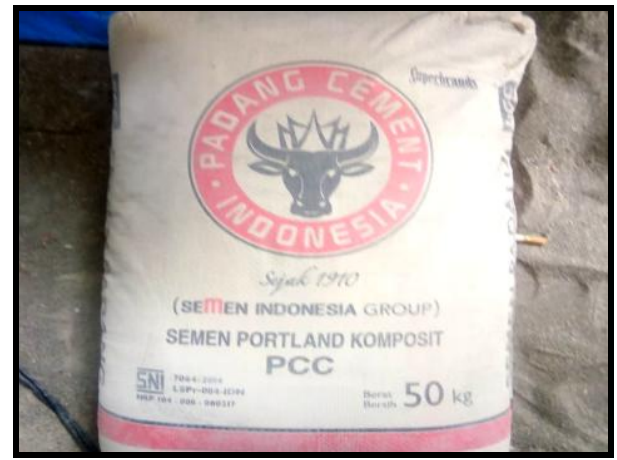

Gambar 3. Semen

4. Air

Air (Gambar 4) yang digunakan untuk membuat adukan telah memenuhi syaratsyarat yaitu air yang bersih, tidak mengandung lumpur, tidak mengandung minyak, tidak mengandung kotoran sampah, dan tidak berbau.

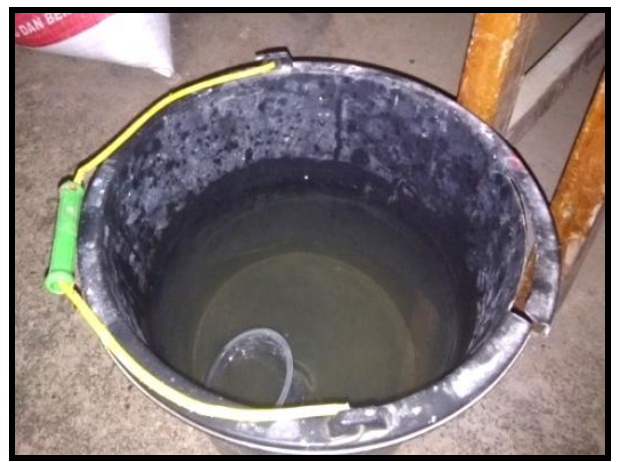

Gambar 4. Air

\section{Pembuatan benda uji}

Pembuatan paving block dimulai dari penimbangan bahan sesuai mix design. Uji sebar dilakukan untuk menentukan banyaknya air yang digunakan dalam campuran mix design yang mengacu pada SNI 03-6882-2002 dengan nilai yang disyaratkan sebesar $105 \%-115 \%$. Hasil uji sebar pasta dapat dilihat pada Tabel 2 .

Perhitungan bahan campuran adukan paving block dihitung dengan perbandingan berat volume semen. Jumlah total benda uji yang dibuat adalah 35 benda uji untuk 7 variasi dengan 5 buah benda uji untuk 1 variasinya. Hasil mix design dapat dilihat pada Tabel 3.

Tabel 2 Hasil Uji Sebar Pasta 


\begin{tabular}{|c|c|c|}
\hline No. & Variasi & $\begin{array}{c}\text { Diameter } \\
\text { Rata-rata }(\mathrm{cm})\end{array}$ \\
\hline 1 & $0 \%$ & 21 \\
\hline 2 & $2,5 \%$ & 21 \\
\hline 3 & $5 \%$ & 20,62 \\
\hline 4 & $7,5 \%$ & 20,87 \\
\hline 5 & $10 \%$ & 20,62 \\
\hline 6 & $12,5 \%$ & 20,87 \\
\hline 7 & $15 \%$ & 20,62 \\
\hline
\end{tabular}

Tabel 3. Hasil Mix Design

\begin{tabular}{|c|c|c|c|c|c|}
\hline No. & Variasi & $\begin{array}{c}\text { Berat } \\
\text { ASKS (gr) } \\
\text { (5 sampel) }\end{array}$ & $\begin{array}{c}\text { Berat } \\
\text { Semen (gr) } \\
(5 \text { sampel) }\end{array}$ & $\begin{array}{c}\text { Berat } \\
\text { Pasir (gr) } \\
(5 \text { sampel) }\end{array}$ & $\begin{array}{c}\text { Berat } \\
\text { Air (gr) } \\
(5 \text { sampel) }\end{array}$ \\
\hline 1 & $0 \%$ & 0 & 2070 & 7290 & 646 \\
\hline 2 & $2,5 \%$ & 17,63 & 2070 & 7290 & 666 \\
\hline 3 & $5 \%$ & 35,25 & 2070 & 7290 & 686 \\
\hline 4 & $7,5 \%$ & 52,88 & 2070 & 7290 & 706 \\
\hline 5 & $10 \%$ & 70,50 & 2070 & 7290 & 716 \\
\hline 6 & $12,5 \%$ & 88,13 & 2070 & 7290 & 726 \\
\hline 7 & $15 \%$ & 105,75 & 2070 & 7290 & 746 \\
\hline \multicolumn{7}{|c|}{ Total } & 370,14 & 14490 & 51030 & 4892 \\
\hline
\end{tabular}

Paving block yang dibuat berukuran $20 \mathrm{~cm} \mathrm{x}$ $10 \mathrm{~cm}$ x $6 \mathrm{~cm}$. Pencetakan paving block dilakukan di pabrik pembuatan paving block. Paving block yang telah dicetak diberikan identitas dan diangin-anginkan selama 24 jam.

\section{Perawatan benda uji}

Paving block yang telah dicetak dan didiamkan selama satu hari kemudian dibawa untuk dilakukan perawatan dengan cara merendam benda uji dalam bak yang berisi air (SNI 03-6825-2002) yang terdapat di Laboratorium Konstruksi dan Teknologi Beton Program Studi Teknik Sipil Fakultas Teknik Universitas Bengkulu. Perendaman dilakukan selama 12 hari. Perawatan dengan perendaman dapat dilihat pada Gambar 5.

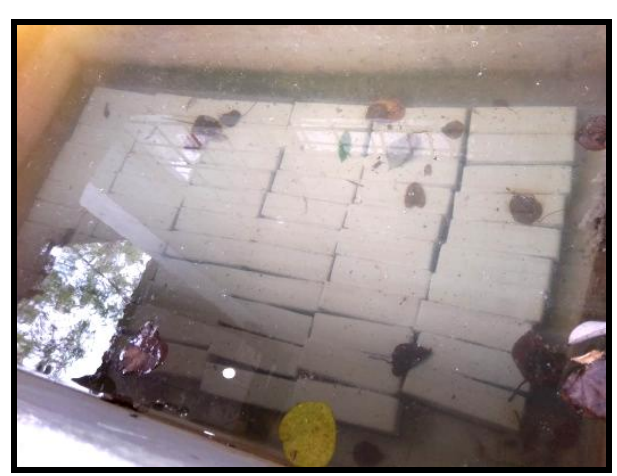

Gambar 5. Perawatan Benda Uji

\section{Pemotongan benda uji}

Pemotongan benda uji dilakukan ketika paving block berumur 13 hari. Benda uji diangkat dari bak perendaman dan didiamkan selama 15 menit kemudian dilakukan pemotongan menggunakan mesin gerinda sehingga benda uji berbentuk kubus sesuai dengan SNI 03-0691-1996 dengan ukuran sisi sebesar $5 \mathrm{~cm}$. Setelah pemotongan selesai, benda uji dianginanginkan selama 24 jam. Pemotongan benda uji dapat dilihat pada Gambar 6.

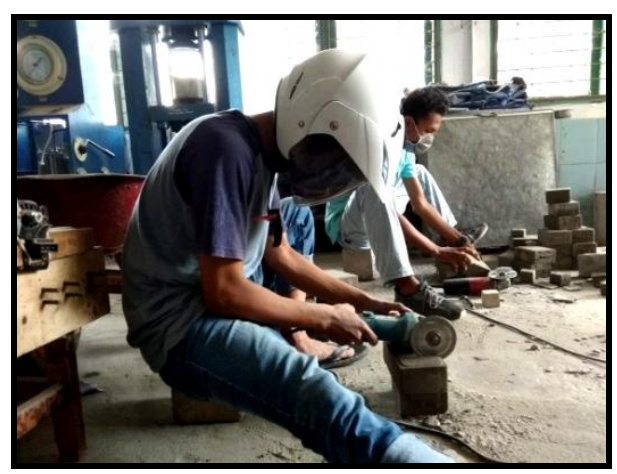

Gambar 6. Pemotongan Benda Uji

\section{Pengujian kuat tekan}

Uji kuat tekan dilakukan di Laboratorium Konstruksi dan Teknologi Beton Program Studi Teknik Sipil Fakultas Teknik Universitas Bengkulu dengan menggunakan mesin uji kuat tekan (Cement Compression Machine). Benda uji yang telah dianginanginkan selama 24 jam setelah dilakukan pemotongan, baru kemudian dilakukan pengujian kuat tekan pada umur paving block 14 hari. 


\section{HASIL DAN PEMBAHASAN}

\section{Kuat tekan paving block}

Hasil pengujian pada Gambar 7, terlihat adanya peningkatan dan penurunan kuat tekan paving block.

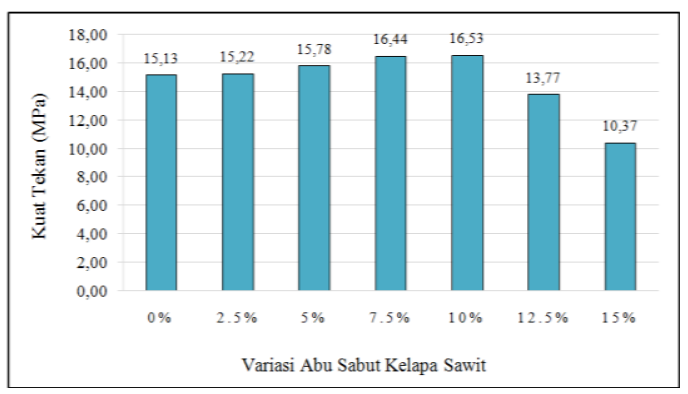

Gambar 7. Grafik Nilai Rata-rata Kuat Tekan Paving Block

Gambar 7 menunjukkan kuat tekan paving block terbesar terjadi pada variasi penambahan ASKS $10 \%$ yaitu sebesar 16,53 MPa. Kuat tekan pada paving block mulai mengalami penurunan pada variasi penambahan ASKS 12,5\% hingga terjadi penurunan terbesar pada variasi $15 \%$ dengan nilai kuat tekan sebesar 10,37 MPa.

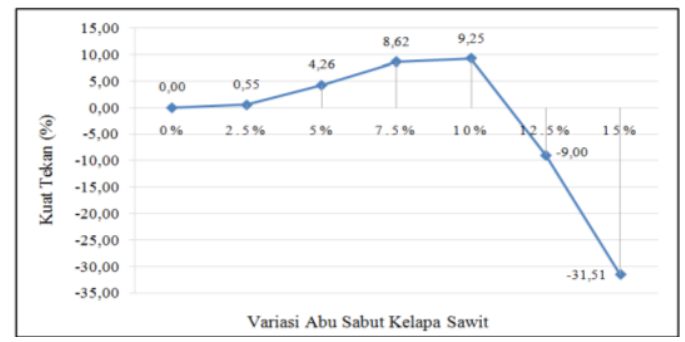

Gambar 8. Grafik Persentase Selisih Nilai Kuat Tekan Rata-rata terhadap Paving Block Normal

Gambar 8 menunjukkan persentase selisih nilai kuat tekan paving block umur 14 hari. Pada variasi $2,5 \%$ hingga $10 \%$ terjadi peningkatan dari paving block normal (Variasi 0\%). Persentase peningkatan nilai kuat tekan mulai terjadi pada variasi 2,5\% yaitu sebesar $0,55 \%$, variasi $5 \%$ sebesar $4,26 \%$, variasi $7,5 \%$ sebesar $8,62 \%$ dan variasi $10 \%$ sebesar $9,25 \%$. Persentase penurunan nilai kuat tekan terbesar terjadi pada variasi $15 \%$ yaitu sebesar $-31,51 \%$.

\section{KESIMPULAN}

Hasil kuat tekan rata-rata paving block pada umur 14 hari dengan menggunakan abu sabut kelapa sawit sebagai bahan penambah semen pada variasi $0 \%, 2,5 \%, 5 \%, 7,5 \%$, $10 \%, 12,5 \%$ dan $15 \%$ secara berturut-turut adalah 15,13 $\mathrm{MPa}, 15,22 \mathrm{MPa}, 15,78 \mathrm{MPa}$, 16,44 MPa, 16,53 $\mathrm{MPa}, 13,77 \mathrm{MPa}$ dan 10,37 MPa. Persentase peningkatan kuat tekan maksimum terhadap paving block normal terjadi pada variasi $10 \%$ dengan peningkatan sebesar $9,25 \%$ dan mengalami penurunan terbesar pada variasi penambahan $15 \%$ dengan penurunan sebesar $-31,51 \%$.

\section{DAFTAR PUSTAKA}

Hambali, M., Lesmania, I., Midkasna, A., 2013, Pengaruh Komposisi Kimia Bahan Penyusun Paving Block terhadap Kuat Tekan dan Daya Serap Airnya, Jurnal Teknik Kimia, Vol. 19, No. 4.

Jalali, N. A., 2017, Pemanfaatan Abu Sabut Kelapa Sawit dan Pengaruhnya Terhadap Karakteristik Batako, Jurnal Teknik Sipil, Vol. 14, No. 1.

SNI 03-0691-1996, Bata Beton (Paving Block), Badan Standarisasi Nasional, Jakarta.

SNI 03-6825-2002, Metode Pengujian Kekuatan Tekan Mortar Semen Portland untuk Pekerjaan Sipil, Departemen Pekerjaan Umum Yayasan Badan Penerbit PU.

SNI 03-6882-2002, Spesifikasi Mortar untuk Pekerjaan Pasangan, Departemen Pekerjaan Umum Yayasan Badan Penerbit PU.

SNI 15-7064-2004, Semern Portland Komposit, Departemen Pekerjaan Umum Yayasan badan Penerbit PU.

Tegar, T., Frieda, Maryanto, 2016, Pemanfaatan Limbah Kelapa Sawit untuk Mereduksi Pemakaian Semen pada Campuran Beton, Jurnal Proyeksi Teknik Sipil, Vol. 2, No. 1 